Article

\title{
The Provision of Visitable Housing in Australia: Down to the Detail
}

\author{
Margaret Ward ${ }^{1, *}$ and Jill Franz ${ }^{2}$ \\ ${ }^{1}$ School of Human Services \& Social Work, Griffith University, University Drive, Meadowbrook, Queensland, \\ 4131 Australia; E-Mail: margaret.ward@griffith.edu.au; Tel: +61-7-3382-1453; Fax: +61-7-3382-1246 \\ ${ }^{2}$ School of Design, Queensland University of Technology, GPO Box 2434, Brisbane, Queensland, 4001 Australia; \\ E-Mail: j.franz@qut.edu.au \\ * Corresponding author
}

Submitted: 30 April 2014 | In Revised Form: 17 June 2014 | Accepted: 3 July 2014 | Published: 9 April 2015

\begin{abstract}
In response to the ratification of the United Nations Convention of the Rights of People with Disabilities (CRPD), Australian housing industry leaders, supported by the Australian Government, committed to transform their practices voluntarily through the adoption of a national guideline, called Livable Housing Design. They set a target in 2010 that all new housing would be visitable by 2020. Research in this area suggests that the anticipated voluntary transformation is unrealistic and that mandatory regulation will be necessary for any lasting transformation to occur. It also suggests that the assumptions underpinning the Livable Housing Design agreement are unfounded. This paper reports on a study that problematised these assumptions. The study used eleven newly-constructed dwellings in three housing contexts in Brisbane, Australia. It sought to understand the logics-of-practice in providing, and not providing, visitable housing. By examining the specific details that make a dwelling visitable, and interpreting the accounts of builders, designers and developers, the study identified three logics-of-practice which challenged the assumptions underpinning the Livable Housing Design agreement: focus on the point of sale; an aversion to change and deference to external regulators on matters of social inclusion. These were evident in all housing contexts indicating a dominant industry culture regardless of housing context or policy intention. The paper suggests that financial incentives for both the builder and the buyer, demonstration by industry leaders and, ultimately, national regulation is a possible pathway for the Livable Housing Design agreement to reach the 2020 goal. The paper concludes that the Australian Government has three options: to ignore its obligations under the CRPD; to revisit the Livable Housing Design agreement in the hope that it works; or to regulate the housing industry through the National Construction Code to ensure the 2020 target is reached.
\end{abstract}

\section{Keywords}

access; Australia; design; inclusive; housing; livable; logics; mandatory; regulation; voluntary

\section{Issue}

This article is part of the special issue "Housing and Space: Toward Socio-Spatial Inclusion", edited by Dr. Dallas Rogers (University of Western Sydney, Australia), Dr. Rae Dufty-Jones (University of Western Sydney, Australia) and Dr. Wendy Steele (RMIT University, Australia).

(C) 2015 by the authors; licensee Cogitatio (Lisbon, Portugal). This article is licensed under a Creative Commons Attribution 4.0 International License (CC BY).

\section{Introduction}

Like many countries, Australia ratified the United Nations Convention on the Rights of People with Disabilities (CRPD) (United Nations, 2007) and committed to supporting the inclusion and participation of all people through the design of the built environment (Australian Government, 2011a, 2011b). Public places and spaces in Australia are now required to meet prescriptive access standards (Australian Government, 2010); however, there are no equivalent access requirements for the private spaces in housing. Instead, Australian governments at the national, state and local levels largely rely on market forces with a mix of goodwill within the housing industry and some incentivisation through government programs (Australian Government, 2009; 
Livable Housing Australia, 2013) to increase social inclusion through housing design. The National Disability Strategy 2010-2020 (Australian Government, 2011a), the Australian Government's formal response to its obligations under the CRPD, describes its policy direction in housing design as follows:

The greater the take up of universal design features, the more open the community is to people with disability, including those with age-related disability. This provides greater choice about where to live, but also more social opportunities for visiting friends and family. (p. 32)

Its key strategy is an agreement in 2010 among leaders from the community sector, the housing industry and government to encourage the housing industry voluntarily to provide "visitability" in all new housing by 2020 (p. 34). Visitability is the capacity for a dwelling to facilitate the inclusion and participation of all people in family and community activities (Concrete Change, 2003; Maisel, 2006; Truesdale, Steinfeld, \& Smith, 2002). The strategy also encourages designers to develop best practice in universal design. Initially called the National Dialogue on Universal Housing Design (NDUHD), the group developed a national guideline, called Livable Housing Design (NDUHD, 2010a) and a strategic plan with the goal of all new housing being visitable by 2020. A not-for-profit company, Livable Housing Australia, was established in 2011 to steer the housing industry towards the 2020 voluntary target (Livable Housing Australia, 2012).

Livable Housing Australia's strategy of education and accreditation stems from its understanding that the buying-market already expects many of the access features to be provided, that the cost is negligible compared to retrofitting these features later, and that the demand for visitable housing will increase due to the ageing population (NDUHD, 2010b). Livable Housing Australia also considers that, with greater awareness among buyers and builders, some minor changes to current building practices, and the use of a voluntary accreditation system, the housing industry can reach the 2020 goal without government intervention (Livable Housing Australia, 2012).

Many guidelines have been developed over the past twenty years to increase the supply of visitable housing; Lifetime Homes in the United Kingdom (Brewerton, Darton, \& Foster, 1997) and the Australian Standard for Adaptable Housing (Standards Australia, 1995) are indicative examples. Voluntariness, as a strategy for industry transformation, has been shown to fail overseas (Imrie, 2003, 2006, p. 4; Kose, 2003, 2010; Malloy, 2009; Nishita et al., 2007) and in Australia (Karol, 2008; Ward, 2013; Ward, Franz, \& Adkins, 2012) to make any discernable systemic change in industry behaviour. The housing industry also resists mandated approaches for a variety of reasons, including cost, minimal demand at the point-of-sale, and a concern over the validity of the advocated need (Imrie, 2006, pp. 45-67; Milner \& Madigan, 2001; Nishita et al., 2007). In the light of this evidence, it is not surprising that Livable Housing Australia has achieved minimal progress towards the 2020 goal (Livable Housing Australia, 2013).

This paper questions why the housing industry has made minimal progress and suggests what might be required to meet the 2020 target. The contribution to knowledge this paper offers is threefold: it problematises the assumptions behind Livable Housing Australia's voluntary approach; it attempts to understand the patterns of responses by individual housing providers to the eight features of Livable Housing Australia's visitability guideline-down to the detail; and it identifies three logics-of-practice which signpost what might be required of the housing industry if the Australian Government is committed to social inclusion through better housing design.

The Australian housing industry is highly competitive with the production of new housing primarily governed by cost and demand-driven trends. It uses relatively simple construction techniques using semi-skilled labour where possible, standard-sized items and economies of scale within strict timelines (Murray, Ramirez-Lovering, \& Whibley, 2008). It relies on regulators and planners to set minimum standards (Dalton, Chhetri, et al., 2011, p. 24). Ninety-five percent of Australian housing is privately-developed (Australian Institute of Health and Welfare, 2013), with three-quarters of the housing stock in the form of single-family dwellings (National Housing Supply Council, 2011, p. 10). Small businesses dominate the Australian housing industry, and they are connected with manufacturers, finance intermediaries and land developers forming a complex interdependent network (Dalton, Chhetri, et al., 2011, p. 39). Most new dwellings are built speculatively for sale at completion, with capacity for some minor cosmetic changes within set designs (Dalton, Wakefield, \& Horne, 2011). Any changes to established practices risk time-delays and unexpected costs; these have a domino effect which reverberates beyond the original providers to others within this complex network (Bringolf, 2011, p. 281).

The lack of responsiveness by the housing industry to build more visitable housing has resulted in advocacy for regulation for visitability in all new housing through the National Construction Code and State- and Territorybased building legislation (Australian Network for Universal Housing Design, 2013; Civil Society Project Group, 2012; Disability Investment Group, 2009). The advocates consider visitability in housing as a human right, similar to the equitable access now required in public spaces and places. They consider legislating for visitability in housing to be necessary if people with disability are to be included like everyone else in family and community life. 
These divergent positions, with Livable Housing Australia's poor outcomes to date, serve to question the validity of the assumptions behind the original agreement. One assumption is that individual housing providers will voluntarily change their practices to consider the needs of future users; that is, to "enhance the quality of life for all occupants at all stages of their life (sic) by including safer and more user-friendly design features" (NDUHD, 2010b, p. 1). Another assumption is that individual housing providers will change voluntarily because the agreed visitability guideline is reasonable, doable and fair within the current business environment (p. 7). A third assumption is that individual housing providers will "do their bit" for social inclusion, rather than be directed to do so by an external regulator (pp. 8-10).

The paper first explores these three assumptions drawing on the current literature. It then reports on a study, which examined the current response to providing the eight features of visitability defined in the Livable Housing Design agreement and identified three logicsof-practice. The paper concludes by suggesting what might be required if the 2020 target is to be reached.

\section{Three Core Assumptions Underpinning the Livable Housing Design Agreement}

\subsection{Assumption 1: Buyers and Builders of New Housing Will Consider the Needs of Future Users}

At first glance, the resistance against both voluntary transformation and regulation towards visitable housing appears logical; in a market-driven economy experiencing minimal demand for visitable housing, there is little reason for individual housing providers to change what works for them now. Australia's peak housing industry body argues that, unless the demand increases substantially or individuals pay extra for it, there is no reason for a change that increases production costs. Further, modifying existing housing offers the housing industry important additional business (Housing Industry Association, 2011). In this regard, it could be said there is little incentive for individual housing providers to design in features which anticipate the needs of future users or to consider sustainable design practices to extend the life of the dwelling.

Given the advocacy for visitable housing, it is useful to consider why there is a lack of demand at the pointof-sale. The population in Australia is ageing and with it, becoming more disabled (Australian Bureau of Statistics, 2010, p. 2). Older people should be potential buyers, given their preference for home-ownership and high incidences of disability and frailty; however, most wish to remain in their existing housing and communities for as long as possible, and investment in modifications is the preferred solution over the purchase of a new dwelling away from their established networks (Judd et al., 2010). Beer and Faulkner's (2009) study into the housing careers of Australians identifies that another potential buyer-group-families of younger people with disability-have particular challenges in establishing their home near support services, employment and transport. Once these services are in place, these families are less likely than other families to move to a new dwelling. Imminent retirees, or "baby-boomers" are another potential demand group; they want to stay active and involved in community life for a long time (Ozanne, 2009). Further, they are more mobile than the previous generation, changing their housing a number of times after they retire. They consider their housing more as an investment than as a stable familybase (Beer \& Faulkner, 2009). With some exceptions, this group is not as yet showing signs of planning for their future frailty, illness or disability or caring for an ageing or ill partner in their housing decisions (Judd et al., 2014, p. 98; Spanbroek \& Karol, 2006).

Buyers of new housing generally have been found to be unwilling to pay extra for features for the "common good", particularly if they do not consider they will personally benefit (Crabtree \& Hes, 2009). Investors also do not consider visitable housing a priority for tenants (Beer \& Faulkner, 2009; Jones, de Jonge, \& Phillips, 2008). In summary, the people who need visitable housing appear the least likely to buy new housing, and the people most likely to buy new housing are not demanding visitable features. This challenges the first assumption of the Livable Housing Design agreement that both buyers and builders of new housing will consider the needs of future users in their decisionmaking.

\subsection{Assumption 2: The Housing Industry Will Transform Voluntarily in the Current Business Environment}

Previously noted, the Australian housing industry depends on a complex network of suppliers, contractors and subcontractors creating interdependence, each affecting the other. Individual providers remain competitive through the use of standardised designs and building practices, tight schedules and volume building with minor cosmetic add-ons to give a market edge (Dalton, Wakefield, et al., 2011; Murray et al., 2008). Individual providers have been found to respond to one-off requests for visitability either by charging significantly above the cost of the changes or by sending the buyer elsewhere (Ward, 2013; Bringolf, 2011).

Recent assessments indicate the cost of providing these minimum access features in new construction is low (Victorian Government, 2010); however, the housing industry refutes this (Housing Industry Association, 2010) arguing the cost to housing providers is not so much in the change in design but in the process of changing established practices to build the new design. The policy-position of the housing industry is that in- 
creased demand is the best strategy to transform practice, and direct government assistance will be necessary to make the provision of access features affordable in bespoke dwellings (Housing Industry Association, 2011). Without these, changing voluntarily to meet the Livable Housing Design guideline simply does not make good business sense. This challenges the second assumption.

\subsection{Assumption 3: The Housing Industry Will "Do Their Bit" for Social Inclusion}

The CRPD and the Australian Government's obligations as set out in the National Disability Strategy bring a particular focus to the broadly accepted right to social inclusion by promoting the right for people with disability to access all aspects of the physical and social environment on an equal basis with others (Australian Government, 2011a; United Nations, 2007). The CRPD not only directs how housing assistance is offered- "[people have the right] to choose their place of residence and where and with whom they live on an equal basis with others" and so forth (United Nations, 2007, Article 19)-it also challenges how housing should be designed-"the design of...environments... [should] be usable by all people, to the greatest extent possible, without the need for adaptation or specialised design" (Article 4).

The Australian Government is accountable to the international community to ensure that the rights set out in these treaties are respected, protected and fulfilled. The obligations to the right to appropriate housing are considered to be progressively realisable; that is, Australia does not need to comply with this obligation immediately, but must work to fulfil these obligations over time. Further, any progressive action is obliged to match the level of resources available to it (People with Disability Australia, 2010). The broad support from government, community and the housing industry for the Livable Housing Design agreement confirms that the 2020 target should and can be met, and that, if it is not met, alternative action should be taken.

The lack of visitability in housing excludes many older people and people with disability; they cannot find suitable housing nor can they visit other people's homes, and this contributes to their isolation, marginalisation and exclusion (Beer \& Faulkner, 2008). Further, by not requiring visitability at the time of construction, the housing industry shifts the costs of retrofitting to future residents and the secondary costs of exclusion to the health, disability and aged-care budgets (Saugeres, 2010). The recent major reforms for aged-care (Productivity Commission, 2011a) and disability (Productivity Commission, 2011b) in Australia are designed to support people in their homes and connected to their informal networks for as long as possible before they resort to costly specialised residential facilities. These programs are relying on the success of the Livable Housing Design agreement to increase the supply of visitable housing, and eventually to build inclusive communities in the long-term. The Livable Housing Design agreement suggests that the housing industry has accepted this responsibility.

Yet as noted earlier, the housing industry has traditionally handed the responsibility for the long-term planning, policy development, and safeguarding community expectations to government planners and regulators through the National Construction Code (Dalton, Chhetri, et al., 2011, p. 24) and there are a number of benefits for stakeholders in doing so. A standard can be negotiated and agreed upon with buyers who do not understand what to look out for in the building process (this is particularly the case for home-purchasers); governments can manage the unintended impacts of a market-driven industry on other policy areas; and the cost of higher standards can be mitigated if everyone complies (Productivity Commission, 2004, p. 92). The National Construction Code acts as a safeguard so that community expectations for safety, health, environmental and social obligations are met within a competitive housing-market. The Productivity Commission describes the particular dilemma in relying on marketforces to ensure visitability in housing:

Governments sometimes intervene in the market for the social purpose of ensuring certain minimum standards of accommodation (including access to buildings) for all. It is most unlikely that certain building qualities, such as access for people with disabilities, would be delivered widely in the absence of government intervention. (p. xxiii)

The lack of response to date challenges the third assumption that individual housing providers will voluntarily "do their bit" for social inclusion and that government intervention in the housing-market will not be required.

The paper now turns to the study of the current response to providing Livable Housing Design's visitable standard and how the individual features were and were not provided. The next section describes the research design and is followed by a report on the findings. The paper then discusses these findings and concludes by suggesting the options open to the Australian Government to increase the provision of visitable housing.

\section{Research Design}

This qualitative study was situated in Brisbane, Australia and used the Livable Housing Design agreement's eight minimum features, described in the housing industry agreement in 2010, as the benchmark for visitability (NDUHD, 2010a), as listed below:

1. Access to dwelling: Step-free access to an entry door;

2. Entry: A step-free entry through that door; 
3. Car space: Minimum $5400 \mathrm{~mm}$ x $3800 \mathrm{~mm}$ car space, if a car space is provided;

4. Doorways/corridors: Minimum $820 \mathrm{~mm}$ doorways and $1000 \mathrm{~mm}$ wide corridors at the entry level;

5. Toilet: Minimum $1200 \mathrm{~mm} \times 900 \mathrm{~mm}$ space in front of one toilet on the entry level;

6. Shower: Step-free shower if a shower is provided on the entry level;

7. $5 \mathrm{~mm}$ transitions: Floor level transitions of less that $5 \mathrm{~mm}$ throughout the entry level; and

8. Reinforcement: Reinforcement in the walls of the bathroom and shower for future installation of grabrails.

The eleven dwellings were chosen as a theoretical sample from three housing contexts: social (that is, subsidised community-managed and public) housing; private housing; and housing provided under the auspice of the Queensland Government's former Urban Land Development Authority (ULDA), an initiative to increase the supply of affordable housing. Each dwelling was identified as ordinary or mainstream; that is, not designed specifically for people with disability or older people. Each housing context had a different imperative for, and experience in, providing housing with access features. The social-housing developments were required to provide a percentage of housing designed specifically for ageing and disabled tenants (Queensland Government, 2008). Private-housing developments had no requirements. Ten per cent of the housing within ULDA multi-unit developments was required to comply with the in-house access guidelines (Urban Land Development Authority, 2011). See Figure 1 for a description of the dwellings in their housing contexts.

Each dwelling was visited at the time of practical completion prior to occupation, at which time each feature was photographed and documented. These data were then compared with the contract drawings and specifications. The interviewer then invited the personnel who best filled the roles of developer, designer and contracted builder to participate in an hour-long interview. Each of the twenty-eight interviewees discussed the eight features and accounted for the provi- sion (or lack of provision) of the eight features as outlined in the Livable Housing Design visitable standard (see listed above).

The analysis of the data consisted of three steps:

1. Analysis of the interviewees' accounts; that is, what they thought of the individual features in the visitable standard;

2. Analysis of the features, taking into consideration the interviewees' accounts, the contract documents and the researcher's observations of the dwellings; and

3. Identification of the reason why the feature was or was not provided. These were grouped into themes and categories within the themes.

This last step is illustrated by the analysis of the change of level into the bathroom in a social-housing apartment. The dwelling was a one-bedroom unit in a socialhousing development, funded by the Nation-Building Economic Stimulus Plan (Australian Government, 2009). The funding agreement required all the dwellings to "facilitate better access for persons with disability and older people where appropriate" (p. 22) and, to this end, some access features were specified. The specifications omitted the requirement of internal step-free transitions. The result was a step of $30 \mathrm{~mm}$ into the bathroom (see Figure 2).

The designer explained why the $30 \mathrm{~mm}$ step occurred:

That is the cheapest way of building in apartments, unfortunately. Structurally, what it means is that concrete structural slab just goes through and, on top of that, they just put the topping slab to get the falls to the floor waste-cheap and nasty. To actually get the set-downs for the bathrooms is quite expensive-because we have $30 \mathrm{~mm}$ on top of the structural slab we can take out $10 \mathrm{~mm}$ for the shower to work which is how we achieved that. But to actually take out the $30 \mathrm{~mm}$ out of the structural slab would add a lot of cost to the project.

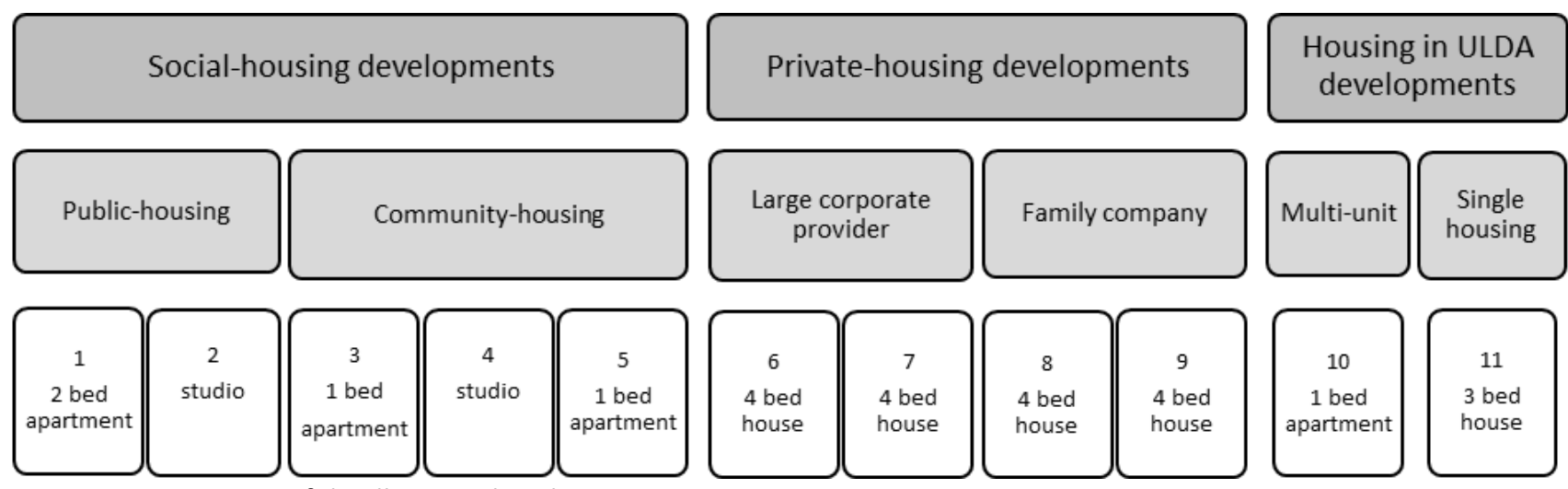

Figure 1. Description of dwellings in their housing contexts. 


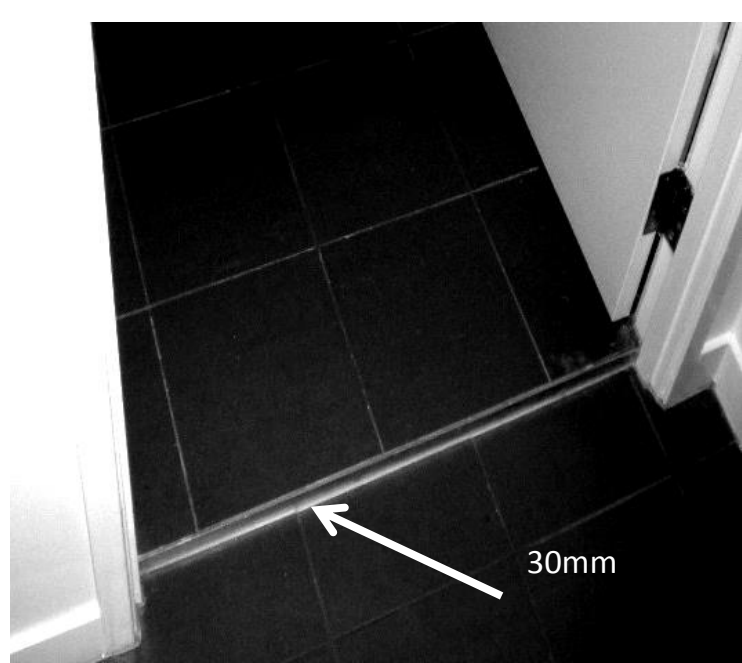

Figure 2. Step into the bathroom.

The construction of this step may have been due to a conscious assumption that the future users would not require a step-free entry; however, given the overall intention of the dwelling to be "universal" and the reason offered above for providing the step ("cheap and nasty" building solution), the researcher interpreted that this feature was provided as a result of a "lack of thought" about the outcome of the builder's usual practice.

\section{Findings}

Overall, thirty-nine of the total of eighty-eight features (eight features in the eleven dwellings) or $44 \%$ complied with the Livable Housing Design visitability guideline. The compliant features were evenly spread over the different housing contexts and there was consistency in compliance for some features. Regardless of the differing purposes for the housing contexts, the building practice and logic behind it were similar (see Table 1).

No dwelling provided all the visitable features, and no single feature was provided consistently in all of the dwellings. The incidence of compliant features was relatively even across all housing contexts, regardless of the dwelling's context, cost, or size. No single-housing context stood out as providing more features above the others. Some features were more prevalent than others; for example, the step-free access to an entry door was provided in most cases because the dwellings had either driveways to internal garages or lift access. On the other hand, reinforcement in the walls of the bathroom and shower was provided in only two dwellings-where it was a funding requirement. Two themes emerged for non-compliance- "lack of thought" and "otherness", and three themes for compliance- "fashion", "requirement" and "cost-effectiveness". These are now described:

\subsection{Non-Compliance-Lack of Thought}

The interviewees explained that some features did not comply because they "forgot" or they simply did not consider how it would result. This unconsciousness about what they were doing or the consequence for the users was identified in two places: a small step into the dwelling, and the transition from the corridor into the bathroom (see Table 2).

For each feature, the built-form differed from the design because of expedient building practice or imprecise specification. The design of the bathrooms suggested a step-free transition; however, the construction resulted in a small lip of between $30-50 \mathrm{~mm}$. An example was the $30 \mathrm{~mm}$ lip at the entry of the bathroom of a social-housing dwelling, which was meant to be designed to universal design principles as part of the $\mathrm{Na}$ tion-Building Economic Stimulus Plan. The designer of a private house explained why the step into the bathroom had resulted; he said: "Oh, I think we forgot to lower the slab". Three social-housing apartments had a $30 \mathrm{~mm}$ step at the front door for a similar reason; the finished floor level external to the dwelling did not align with the finished floor level inside the dwelling even though the contract documents did not indicate a step (see Figure 3 as an example).

Table 1. Distribution of compliant features.

\begin{tabular}{|c|c|c|c|c|c|c|c|c|c|c|c|}
\hline \multirow[b]{2}{*}{ Dwelling } & \multicolumn{5}{|c|}{ Social-housing } & \multicolumn{4}{|c|}{ Private-housing } & \multicolumn{2}{|c|}{ ULDA } \\
\hline & 1 & 2 & 3 & 4 & 5 & 6 & 7 & 8 & 9 & 10 & 11 \\
\hline \multicolumn{12}{|c|}{ Access to dwelling } \\
\hline \multicolumn{12}{|l|}{ Entry } \\
\hline \multicolumn{12}{|l|}{ Car space } \\
\hline \multicolumn{12}{|c|}{ Doorways/corridors } \\
\hline \multicolumn{12}{|l|}{ Toilet } \\
\hline \multicolumn{12}{|l|}{ Shower } \\
\hline \multicolumn{12}{|l|}{$5 \mathrm{~mm}$ transitions } \\
\hline Reinforcement & & & & & & & & & & & \\
\hline
\end{tabular}


Table 2. Non-compliant features due to "lack of thought".

\begin{tabular}{|c|c|c|c|c|c|c|c|c|c|c|}
\hline \multirow[b]{2}{*}{ Dwelling } & \multicolumn{4}{|c|}{ Social-housing } & \multicolumn{4}{|c|}{ Private-housing } & \multicolumn{2}{|c|}{ ULDA } \\
\hline & 12 & 3 & 4 & 5 & 6 & 7 & 8 & 9 & 10 & 11 \\
\hline \multicolumn{11}{|l|}{ Access to dwelling } \\
\hline \multicolumn{11}{|l|}{ Entry } \\
\hline \multicolumn{11}{|l|}{ Car space } \\
\hline \multicolumn{11}{|c|}{ Doorways/corridors } \\
\hline \multicolumn{11}{|l|}{ Toilet } \\
\hline \multicolumn{11}{|l|}{ Shower } \\
\hline \multicolumn{11}{|l|}{$5 \mathrm{~mm}$ transitions } \\
\hline Reinforcement & & & & & & & & & & \\
\hline
\end{tabular}

Feature not provided due to "lack of thought"

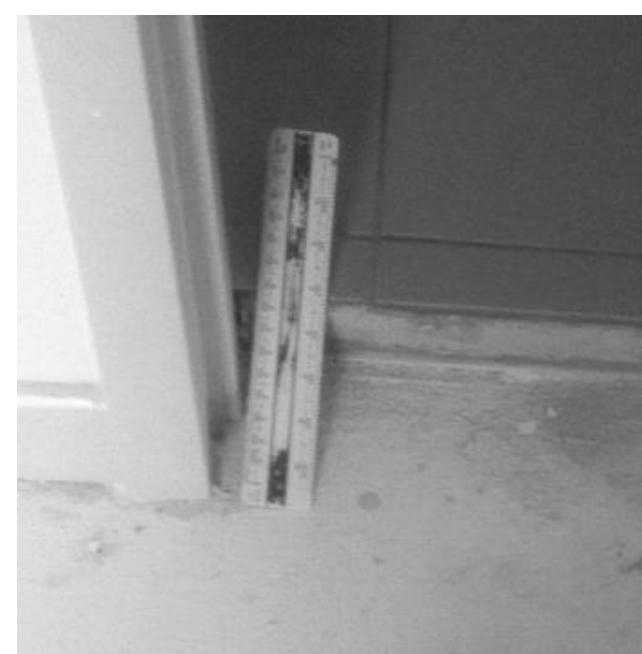

Figure 3. Entry with $30 \mathrm{~mm}$ lip.

All the single-family dwellings provided a step-up into the house from the internal garage. This was due to a traditional and outdated building practice. A developer explained:

It's actually an expense to incorporate that step... because you are not required to have it. It was more the type of termite barrier that we provide, um, which has a step-down-so we have a physical barrier-a visual barrier, um, and it works very sweetly with the car access as it actually sits down $86 \mathrm{ml}$ from the house slab-it's the only reason why the step's there.

\subsection{Non-Compliance- "Otherness"}

The interviewees' responses to the rest of the features that were non-compliant suggested a conscious decision that visitability would not be necessary; that is, people with mobility limitations would not be residing or visiting the dwellings (see Table 3 ).

This was the largest theme and three categories or reasons were identified. The first category was that the cost of the dwelling was given priority over the access needs of prospective minority groups. The developer of ULDA housing explained his decision to make the corridors and doorways narrow: "It's mainly the corridor widths that have to increase and things like that, that decrease the efficiency of our floor plans-that's the big concern". The developer of a social-housing dwelling argued that cost could not be compromised by the needs of a small minority group:

And again, you got to say-what's it really trying to achieve? Is it for a wheelchair access? But you got to look at, you know, the people that live in units, how many are in a wheelchair? I mean, what's the real [number]? And yet, you don't want to take someone's right away to live in that but it's-you can't design a whole building for the-that's where the cost gets, gets out of whack.

The second category was that the prospective buyer would not consider visitability to be a priority. The developer of a four-bedroom house explained why he was unwilling to widen the corridor: "The houses have got to become bigger, or have smaller rooms. So that's a big factor-the people won't like it-the clients". The third reason was an assumption that the occupants would be ambulant. A privately-developed house had steps designed into the corridor to the main living area. Its developer considered his dwelling did not require accessibility: "The public-housing sector does actually look after those people-with specific-designed homes. I know that because I have quoted on them".

\subsection{Compliance-Fashion}

Interviewees reported they provided some features because they were considered to be fashionable or aspirational. These features occurred in private and ULDA developments and were absent in the social-housing developments (see Table 4).

The private and ULDA dwellings, for example, provided wide driveways to internal garages that were suit- 
able for wheelchair access. A number of these dwellings also had at least one bathroom which could accommodate a step-free shower and the pre-requisite space in front of the toilet. A developer of private housing said: "A lot of those items are, from an architect's perspective, from an architectural style, largely aspirational". These features were not provided to improve access for people with disability; rather, accessibility was an unintentional consequence of a fashion trend.

\subsection{Compliance-Client Requirements}

This theme identified that features were provided because they were contract requirements of the dwellings. They were found in the social-housing and ULDA dwellings only. No features within this category were found in privately-developed housing (see Table 5).

Table 3. Non-compliant features due to "otherness"

\begin{tabular}{|c|c|c|c|c|c|c|c|c|c|c|c|}
\hline \multirow[b]{2}{*}{ Dwelling } & \multicolumn{5}{|c|}{ Social-housing } & \multicolumn{4}{|c|}{ Private-housing } & \multicolumn{2}{|c|}{ ULDA } \\
\hline & 1 & 2 & 3 & 4 & 5 & 6 & 7 & 8 & 9 & 10 & 11 \\
\hline \multicolumn{12}{|c|}{ Access to dwelling } \\
\hline \multicolumn{12}{|l|}{ Entry } \\
\hline \multicolumn{12}{|l|}{ Car space } \\
\hline \multicolumn{12}{|c|}{ Doorways/corridors } \\
\hline \multicolumn{12}{|l|}{ Toilet } \\
\hline \multicolumn{12}{|l|}{ Shower } \\
\hline \multicolumn{12}{|l|}{$5 \mathrm{~mm}$ transitions } \\
\hline Reinforcement & & & & & & & & & & & \\
\hline
\end{tabular}

Feature not provided due to "otherness"

Table 4. Compliant features due to "fashion".

\begin{tabular}{|c|c|c|c|c|c|c|c|c|c|c|}
\hline \multirow[b]{2}{*}{ Dwelling } & \multicolumn{5}{|c|}{ Social-housing } & \multicolumn{3}{|c|}{ Private-housing } & \multicolumn{2}{|c|}{ ULDA } \\
\hline & 1 & 2 & 3 & 4 & 5 & 6 & 8 & 9 & 10 & 11 \\
\hline \multicolumn{11}{|c|}{ Access to dwelling } \\
\hline \multicolumn{11}{|l|}{ Entry } \\
\hline \multicolumn{11}{|l|}{ Car space } \\
\hline \multicolumn{11}{|c|}{ Doorways/corridors } \\
\hline \multicolumn{11}{|l|}{ Toilet } \\
\hline \multicolumn{11}{|l|}{ Shower } \\
\hline \multicolumn{11}{|l|}{$5 \mathrm{~mm}$ transitions } \\
\hline Reinforcement & & & & & & & & & & \\
\hline
\end{tabular}

Feature provided due to "fashion"

Table 5. Compliant features due to client requirements

\begin{tabular}{|c|c|c|c|c|c|c|c|c|c|c|c|}
\hline \multirow[b]{2}{*}{ Dwelling } & \multicolumn{5}{|c|}{ Social-housing } & \multicolumn{4}{|c|}{ Private-housing } & \multicolumn{2}{|c|}{ ULDA } \\
\hline & 1 & 2 & 3 & 4 & 5 & 6 & 7 & 8 & 9 & 10 & 11 \\
\hline \multicolumn{12}{|c|}{ Access to dwelling } \\
\hline \multicolumn{12}{|l|}{ Entry } \\
\hline \multicolumn{12}{|l|}{ Car space } \\
\hline \multicolumn{12}{|c|}{ Doorways/corridors } \\
\hline \multicolumn{12}{|l|}{ Toilet } \\
\hline \multicolumn{12}{|l|}{ Shower } \\
\hline \multicolumn{12}{|l|}{$5 \mathrm{~mm}$ transitions } \\
\hline Reinforcement & & & & & & & & & & & \\
\hline
\end{tabular}

Feature provided due to client requirements 
Two social-housing dwellings were built with government funding which required the provision of a stepfree shower and reinforcement in the walls of every bathroom in the development (Australian Government, 2009). A designer described the influence of the funding guidelines; once a feature became a condition of the contract, it was provided without question: "[Not complying] hit people in the back pocket, and they feel it and it hurts". The builder indicated that the purpose behind these extra building requirements was of little interest as long as they were included in the contract; if a feature was required, then it was provided:

Well, we just do what's on the plans-if we are told to do it, we do it. And we don't argue. If we are told to do it, we do it. There's no big deal, as long as you know you're doing it beforehand.

\subsection{Compliance-Cost-Effective Practice}

In this theme, the interviewees identified that the features were provided at the discretion of the housing provider. They were not required by the funder, nor were they considered aspirational; rather, they were provided because they were considered to be costeffective (see Table 6).

Three categories of reasons were identified. The first category was that they chose to provide access features in readiness for possible legislative changes. Some interviewees understood that legislative changes were imminent (they were enacted during the study), so they chose to provide the features ahead of time, rather than having to make changes later. The builder of social-housing dwelling explained:

So, particularly with the type of construction that [we do], which is the multi-unit developments, the requirements for us to meet the design code and obviously building approvals, et cetera, are actually required to build...for access and egress for people with disabilities.
The second category was that it was cost-effective practice to repeat throughout the whole development any "special" features that were required in some of the dwellings. This practice occurred in some socialhousing dwellings which were adjacent to dwellings specially designed for people with physical disability. The mainstream apartments of a ULDA development had the same entry detail as the accessible apartments. The designer explained how the development company considered the provision of access features:

I believe [the features are] fairly logical, so I don't believe it-for the most part-it's not very onerous on a client or a builder or a developer or anything like that at all. So wherever we can provide beyond a minimum is a good thing and I think that's good design generally.

The third category was that the provision of access features aligned with good building-practice. With regard to step-free entry to a bathroom, a builder explained:

Dropping the slab [for drainage in the bathroom], it is standard practice for us, just for waterproofing purposes...We've never had any issues down the path with waterproofing, um, because we have gone over and above what was required.

In summary, when providing the eight features for visitability, the interviewees identified two themes for non-compliance ("lack of thought" and "otherness") and three themes for compliance ("fashion", "requirement' and "good practice"). Although all dwellings provided some features, no dwelling provided a coherent path of travel necessary to make a dwelling visitable. Some examples of this incoherence were: a step-free driveway which led to a step at the door; a wide front door which led to a narrow corridor; and a narrow internal doorway which did not allow entry of a wheelchair to a spacious bathroom. The provision of these access features separately and severally did not provide visitability as an outcome in any of the dwellings.

Table 6. Compliant features due to cost-effective practice.

\begin{tabular}{|c|c|c|c|c|c|c|c|c|c|c|}
\hline \multirow[t]{2}{*}{ Dwelling } & \multicolumn{3}{|c|}{ Social-housing } & & \multicolumn{4}{|c|}{ Private } & \multicolumn{2}{|c|}{ ULDA } \\
\hline & 12 & 3 & 4 & 5 & 6 & 7 & 8 & 9 & 10 & 11 \\
\hline \multicolumn{11}{|l|}{ Access to dwelling } \\
\hline \multicolumn{11}{|l|}{ Entry } \\
\hline \multicolumn{11}{|l|}{ Car space } \\
\hline \multicolumn{11}{|c|}{ Doorways/corridors } \\
\hline \multicolumn{11}{|l|}{ Toilet } \\
\hline \multicolumn{11}{|l|}{ Shower } \\
\hline \multicolumn{11}{|l|}{$5 \mathrm{~mm}$ transitions } \\
\hline Reinforcement & & & & & & & & & & \\
\hline
\end{tabular}

Feature provided voluntarily due to cost-effective practice 


\section{Discussion}

Although this study was limited in size and scope, the five themes identified for providing and not providing the individual features of Livable Housing Design agreement's visitability guideline reflect previous research in this area (Bringolf, 2011; Imrie, 2006; Nishita et al., 2007). These findings extend this knowledge by identifying patterns of provision or non-provision of the individual access features, and these patterns suggest the following:

- The over-riding culture within the housing industry defines the quality of design and detailing, disregarding the policy intentions underpinning the housing context (in this study, private developments, increased supply of affordable housing and social-housing for people in need);

- Many individual access features are currently provided in mainstream housing; however, they are provided sporadically and incoherently, and do not lead to visitability; and

- Current practices will not provide visitability until its purpose towards social inclusion is understood by everyone; and is required as part of the contractual arrangements.

The findings suggest that within the housing industry three logics-of-practice prevail: optimal profit at the point-of-sale; resistance to change generally; and deference to external regulators for direction on broader policy impacts such as social inclusion. These logics-ofpractice offer some insight into why the voluntary approach of the Livable Housing Design agreement in its current form will fail, and what might assist to reach the 2020 target.

\subsection{Optimal Profit at the Point-of-Sale}

A reason for not providing the features was the assumption that prospective buyers do not and will not require visitability; that those who do need it are not part of their market or will be catered for elsewhere. This supports previous research by Bringolf (2011), Imrie (2006) and Nishita et al. (2007) and is a reflection of the acceptance of the exclusion of people with disability and older people in Australian culture (COTA, 2010; National People with Disabilities and Carer Council, 2009). Nevertheless, the interviewees were willing to provide visitable features if it benefitted their practice and led to optimal profit at the point-of-sale.

The Livable Housing Design agreement appears to have missed this point. The current strategies of information, awareness-raising and accreditation are unlikely to transform their established practice until there is a profit incentive to do so. The study showed that where financial gain was contingent on the provision of certain features, they were provided without question. Perhaps if the accreditation of dwellings resulted in clear financial benefits either to the housing provider or to the buyer as is the case in Japan (Kose, 2003), the housing industry might respond.

\subsection{Resistance to Change Generally}

There was no suggestion that the individual features were difficult to build; rather, the reasons for noncompliance identified entrenched building practices and unconsciousness of the consequences of current building practices for users. The interviewees' reluctance to transform their practices appeared more an issue of "risk" than one of cost or difficulty, reflecting Bringolf's (2011, p. 281) domino theory and Imrie's findings that once housing providers were required to change they were unlikely to return to old building practices (Imrie, 2006, p. 123).

A recent analysis by Dalton, Wakefield, et al. (2011, pp. 39-47) suggests the Australian housing industry practices deal with far more costly issues, such as, lengthening construction times, managing demand for a greater variety of add-ons, the scheduling of a large number of contracts and suppliers, and the rectification of poor-quality work. To change practices to provide visitable features appears minor in comparison to these other challenges. This suggests a wide-ranging resistance to change, which the Livable Housing Design agreement appears to have underestimated. The housing industry requires a compelling reason to change what currently works, and the knowledge that the individual features are doable and cost-effective within the current business environment is simply not enough. Perhaps if the industry leaders who signed the Livable Housing Design agreement demonstrated how Livable Housing Design could be adopted into their practices without negative impact, this might convince others that the level of risk is small and can be contained without affecting their profit margin.

\subsection{Deference to an External Regulator for Direction on Social Inclusion}

Previously noted, when the features were obligatory, the interviewees complied, incorporating them into their building practices cost-effectively, and without question. This supports the argument by Dalton, Chetri, et al. (2011) that the housing industry in Australia has traditionally handed over the responsibility to meet community standards to regulators through a regulatory regime, and focuses on providing a competitive product within those constraints. This challenges Livable Housing Design agreement's assumption that the housing industry will voluntarily transform for reasons of social inclusion.

Within its limited size and scope, this study antici- 
pates the failure of the Livable Housing Design agreement to reach its 2020 target. Given the logics-ofpractice identified, a transformative plan would require three elements: the first is a significant financial incentive to encourage early-adopters to build and buy visitable housing; the second is demonstration by industry leaders that the changes in practices have minimal risks; and, the third is regulation for visitability in all new housing within the National Construction Code to ensure the 2020 target is met. To hope that the Livable Housing Design agreement might guide best practice in inclusive design is reasonable; to rely on it in its current form to increase social inclusion is fanciful.

\section{Conclusion}

The Australian Government has a human rights obligation to increase the supply of visitable housing with the intent to improve social inclusion, and, given Australia's comparative affluence and growth, it is obliged to act within a reasonable timeline. To this end, it must ensure the Livable Housing Design agreement's 2020 target is met. It is clearly preferable to do this with the support of all stakeholders, including community and housing industry representatives involved; however, this paper argues that the 2020 target will not be met without government intervention.

A new approach is required. The Australian Government has three options: it can ignore its human rights obligations to improve social inclusion through housing design; it can financially incentivise the housing industry to respond voluntarily to the Livable Housing Design agreement; or it can ensure the 2020 target is met by working decisively with housing industry and community leaders towards the regulation of minimum access features in all new housing through the National Construction Code.

\section{Acknowledgements}

The researchers acknowledge the interviewees within this study who candidly and openly explained the reasoning behind their design and building practices.

\section{Conflict of Interests}

The authors declare there are no conflicts of interest.

\section{References}

Australian Bureau of Statistics. (2010). Disability, ageing and carers, Australia: Summary of findings. Retrieved from http://www.ausstats.abs.gov.au/aus stats/subscriber.nsf/0/9C2B94626F0FAC62CA2577F A0011C431/\$File/44300_2009.pdf

Australian Government. (2009). Social-housing initiative guidelines: Element 1-new construction. Nation
Building Economic Stimulus Plan. Canberra: Australian Government.

Australian Government. (2010). Disability (access to premises-buildings) standards 2010: Disability Discrimination Act 1992. Canberra: Australian Government.

Australian Government. (2011a). 2010-2020 National Disability Strategy: An initiative of the Council of Australian Governments. Canberra: Commonwealth of Australia.

Australian Government. (2011b). Our Cities, Our Future: a national urban policy framework for a productive, sustainable and liveable future. Canberra: Department of Infrastructure and Transport. Retrieved from http://www.infrastructure.gov.au/ infrastructure/mcu/files/Our_Cities_National_ Urban_Policy_Paper_2011.pdf

Australian Institute of Health and Welfare. (2013). Housing assistance in Australia 2013. Canberra: Australian Government.

Australian Network for Universal Housing Design. (2013). Home Page. Retrieved from http://www. anuhd.org

Beer, A., \& Faulkner, D. (2008). The housing careers of people with a disability and carers of people with a disability Southern Research Centre. Adelaide: Australian Housing and Urban Research Institute.

Beer, A., \& Faulkner, D. (2009). 21st century housing careers and Australia's housing future. AHURI Final Report No. 128. Retrieved from http://www.ahuri. edu.au/nrv/nrv2/NRV2_Assoc_Docs.html

Brewerton, J., Darton, D., \& Foster, L. (1997). Designing Lifetime Homes. York, UK: Joseph Rowntree Foundation.

Bringolf, J. (2011). Barriers to universal design in housing. Sydney: Urban Research Centre, College of Health and Science. Retrieved from http://handle. uws.edu.au:8081/1959.7/506910

Civil Society Project Group. (2012). Disability rights now: Civil society report to the United Nations Committee on the rights of persons with disabilities. Sydney: Disability Representative, advocacy, legal and human rights organisations.

Concrete Change. (2003). Visitability defined. Retrieved from http://concretechange.org/visitability/visitabi lity-defined/

COTA. (2010). Taking older people seriously: COTA Australia's federal election platform 2010. Adelaide: COTA.

Crabtree, L., \& Hes, D. (2009). Sustainability uptake in housing in metropolitan Australia: An institutional problem, not a technological one. Housing Studies, 24(2), 203-224.

Dalton, T., Chhetri, P., Corcoran, J., Groenhart, L., \& Horne, R. (2011). Understanding the patterns, characteristics and trends in the housing sector labour force in Australia. AHURI Positioning Paper, no.142. 
Melbourne: AHURI.

Dalton, T., Wakefield, R., \& Horne, R. (2011). Australian suburban house building: industry organisation, practices and constraints. AHURI Positioning Paper, no. 143. Melbourne: AHURI.

Disability Investment Group. (2009). The Way Forward. Canberra: Australian Government.

Housing Industry Association. (2010). Submission by the Housing Industry Association to the Department of Planning and Community Development on the regulatory impact statement into visitable and adaptable housing. Retrieved from http://hia.com. au/media/ /media/Files/MediaMicrosite/Submissi ons/Visitable\%20and\%20Adaptable\%20Housing\%2 0-\%20Victoria.ashx

Housing Industry Association. (2011). Accessibility in residential buildings. Retrieved from http://hia. com.au/hia/content/Policy/region/National/classifi cation/Building\%20Policy/article/IS/HP/Accessibi lity\%20in\%20Residentail\%20Buildings.aspx

Imrie, R. (2003). Housing quality and the provision of accessible homes. Housing Studies, 18(3), 387-408.

Imrie, R. (2006). Accessible housing: Quality, disability and design. London: Routledge.

Jones, A., de Jonge, D., \& Phillips, R. (2008). The role of home maintenance and modification services in achieving health, community care and housing outcomes in later life. AHURI final report, no.123. Brisbane: AHURI.

Judd, B., Liu, E., Easthope, H., Davy, L., \& Bridge, C. (2014). Downsizing amongst older Australians. AHURI Final Report No.214. Melbourne: AHURI.

Judd, B., Olsberg, D., Quinn, J., \& Demirbilek, O. (2010). Dwelling, land and neighbourhood use by older home owners. AHURI final report No. 144. Melbourne: AHURI.

Karol, E. (2008). Inclusive design and the new home market: The West Australian situation. Architectural Science Review, 51(1), 80-83.

Kose, S. (2003). The Japanese Experience. In P. Clarkson, R. Coleman, S. Keates \& C. Lebbon (Eds.), Inclusive Design: Design for the whole population (pp. 308-316). London: Springer-Verlag.

Kose, S. (2010). How can the exploding senior population be accommodated? Japanese struggle towards inclusive design. Journal of Engineering Design, 21(2), 165-171.

Livable Housing Australia. (2012). Home Page. Retrieved from http://livablehousingaustralia.org.au/

Livable Housing Australia. (2013). Livable housing update: December 2013. Retrieved March 12, 2014, from http://us7.campaign-archive1.com/?u=07c19bd 51a6060a51154a75fa\&id $=68 \mathrm{~b} 89 \mathrm{~b} 30 \mathrm{fc}$

Livable Housing Australia. (2013). NRAS Applicant and Participant Information. Sydney: Livable Housing Australia.

Maisel, J. (2006). Toward inclusive housing and neigh- borhood design: A look at visitability. Community Development, 37(3), 26-34.

Malloy, R. P. (2009). Inclusion by Design: Accessible Housing and Mobility Impairment. Hastings Law Journal, 60(4), 699-699.

Milner, J., \& Madigan, R. (2001). Politics of accessible housing in the UK. In C. Holland \& S. M. Peace (Eds.), Inclusive housing in an ageing society: innovative approaches. Bristol: Policy Press.

Murray, S., Ramirez-Lovering, D., \& Whibley, S. (Eds.). (2008). reHousing. Melbourne: RMIT Publishing Press.

National Housing Supply Council. (2011). Key findings of the 2011 state of supply report. Canberra: Australian Government.

National People with Disabilities and Carer Council. (2009). Shut Out: The Experience of People with Disabilities and their Families in Australia. Canberra: Australian Government.

NDUHD. (2010a). Livable Housing Design guidelines. Retrieved from http://www.dss.gov.au/our-respon sibilities/disability-and-carers/program-services/ government-international/national-disabilitystrategy/livable-housing-design/livable-housingdesign-guidelines

NDUHD. (2010b). Strategic plan. Retrieved from http://www.dss.gov.au/our-responsibilities/disa bility-and-carers/program-services/governmentinternational/national-disability-strategy/livablehousing-design/national-dialogue-on-universalhousing-design-strategic-plan

Nishita, C., Liebig, P., Pynoos, J., Perelman, L., \& Spegal, K. (2007). Promoting basic accessibility in the home: Analyzing patterns in the diffusion of visitability legislation. Journal of Disability Policy Studies, 18(1), 213.

Ozanne, E. (2009). Negotiating identity in late life: Diversity among Australian baby boomers. Australian Social Work, 62(2), 132-154.

People with Disability Australia. (2010). Accommodating human rights: a human rights perspective on housing, and People with Disability Australia housing and support for persons with disability. Sydney: People with Disability Australia.

Productivity Commission. (2004). Reform of building regulation. Retrieved from http://129.3.20.41/eps/ othr/papers/0506/0506007.pdf

Productivity Commission. (2011a). Caring For Older Australians: Productivity Commission inquiry report. Canberra: Australian Government.

Productivity Commission. (2011b). Disability Care and Support: Productivity Commission inquiry report. Canberra: Australian Government.

Queensland Government. (2008). Schematic Design Brief: Two-bedroom apartments, adaptable. Brisbane: Queensland Government.

Saugeres, L. (2010). (Un)accommodating disabilities: 
housing, marginalization and dependency in Australia. Journal of Housing and the Built Environment, 26(1), 1-15.

Spanbroek, N., \& Karol, E. (2006). Ageing at home-are we prepared? Paper presented at the 2nd International Conference for Universal Design, 23-25 October 2006, Kyoto, Japan.

Standards Australia. (1995). Adaptable housing AS4299. Sydney: Standards Australia.

Truesdale, S., Steinfeld, E., \& Smith, E. (2002). Visitability: An approach to universal design in housing. Buffalo, USA: Rehabilitation Engineering Research Center on Universal Design, School of Architecture and Planning, University at Buffalo.

United Nations. (2007). Convention on the rights of persons with disabilities and optional protocol. Retrieved from http://www.un.org/disabilities/ default.asp ?navid=14\&pid $=150$
Urban Land Development Authority. (2011). Accessible Housing: ULDA guideline No 2. Brisbane: Urban Land Development Authority.

Victorian Government. (2010). Accessible Housing: Public consultation on the visitable and adaptable features in housing regulatory impact statement. Retrieved from http://www.dse.vic.gov.au/DSE/ nrenpl.nsf/LinkView/10E80E70836F36FBCA2575DE 001CFC9EB6D5337005FB3718CA2572CF007A0F0A

Ward, M. (2013). Inclusive housing in Australia; a question of responsibility and distributive justice (PhD Thesis). Brisbane: Queensland University of Technology. Retrieved from http://eprints.qut.edu.au/ 63493

Ward, M., Franz, J., \& Adkins, B. (2012). Inclusive housing in Australia: A voluntary response. Proceedings of World Academy of Science, Engineering and Technology (WASET), 67, 344-352.

\section{About the Authors}
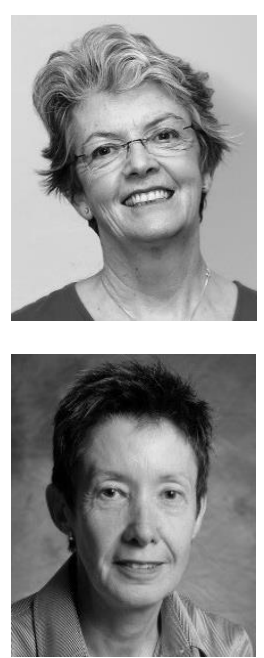

\section{Dr. Margaret Ward}

Margaret Ward is a Research Fellow at the School of Human Services and Social Work, Griffith University in Brisbane, Australia. She recently completed her doctoral thesis at the School of Design at Queensland University of Technology, Brisbane. Dr. Ward is currently convenor of the Australian Network for Universal Housing Design. Originally a practicing architect in the area of housing, she has had a varied career as a policy writer, service provider and advocate in the areas of social inclusion, housing and disability.

\section{Dr. Jill Franz}

Jill Franz is a Professor and Head of Discipline (Interior Design) in the School of Design, Creative Industries Faculty, Queensland University of Technology (QUT). In addition to supervising nine PhD students, Dr. Franz is a Director of the Design for Health and Social Inclusion Research Collective comprising researchers across several faculties of the university undertaking cross-disciplinary collaborative exploration of the relationship between the environment and significant social issues to do with health, wellbeing and social justice. 